\title{
First evidence of the P-glycoprotein gene expression and multixenobiotic resistance modulation in earthworm
}

\author{
Ivana Bošnjak ${ }^{1}$, Ana Bielen ${ }^{1}$, Sanja Babić 2 , Lidija Šver ${ }^{1}$, Natalija Topić Popović ${ }^{2}$ Ivančica \\ Strunjak-Perović2 ${ }^{2}$ Rozelinda Čož-Rakovac ${ }^{2}$, and Roberta Sauerborn Klobučar ${ }^{2}$ \\ Department of Biochemical Engineering, Faculty of Food Technology and Biotechnology ${ }^{l}$, Division of Materials \\ Chemistry, Ruđer Bošković Institute', Zagreb, Croatia
}

Received in July 2013

CrossChecked in February 2014

Accepted in February 2014

\begin{abstract}
Multixenobiotic resistance (MXR) is an important mechanism of cellular efflux mediated by ATP binding cassette $(\mathrm{ABC})$ transporters that bind and actively remove toxic substrates from the cell. This study was the first to identify $\mathrm{ABC}$ transporter P-glycoprotein (P-gp/ABCB1) as a representative of the MXR phenotype in earthworm (Eisenia fetida). The identified partial cDNA sequence of $A B C B 1$ overlapped with ABCB1 homologues of other organisms from $58.5 \%$ to $72.5 \%$. We also studied the effect of five modulators (verapamil, cyclosporine A, MK571, probenecid, and orthovanadate) on the earthworm's MXR activity by measuring the accumulation of model substrates rhodamine $\mathrm{B}$ and rhodamine 123 in whole body tissue of the adult earthworm. MK571, orthovanadate, and verapamil significantly inhibited MXR activity, and rhodamine 123 turned out to better reflect MXR activity in that species than rhodamine B. Our results show that E. fetida can serve well as a test organism for environmental pollutants that inhibit MXR activity.
\end{abstract}

KEY WORDS: $A B C$ transport proteins; cellular detoxification; cyclosporine A; Eisenia fetida, MK571; MXR; orthovanadate; probenecid; soil organism; verapamil

The earthworm (Eisenia fetida) is often used in ecotoxicological research because of its abundance in the soil and the ability to tolerate and bio-accumulate high quantities of contaminants, including man-made chemicals (1-5). Like many other organisms, it can survive in highly contaminated environments thanks to the efflux of toxicants from the cell mediated by transporter proteins and detoxification enzymes (6-7). The most studied efflux transporter proteins involved in the so-called multixenobiotic resistance (MXR) mechanism are ATP-binding cassette (ABC) transporters. These transmembrane proteins, present in all living organisms, interact with a wide number of chemicals, including xenobiotics, and pump them across the cell membrane, preventing their accumulation in the cell (8-10).
The most common MXR transmembrane proteins are P-glycoprotein (P-gp or ABCB1), multidrug resistance-associated proteins (MRPs or ABCC1-3), and breast cancer resistance protein (BCRP or ABCG2) (11-12). P-gp, the first and best-characterised $\mathrm{ABC}$ transporter, is essential for the efflux of substrates across the membrane (13) and highly effective in the tissues of vertebrates and invertebrates (14-19).

Since the measurement of MXR activity can tell a lot about the effects of xenobiotics on $\mathrm{ABC}$ transporters, MXR activity can be used as a biomarker of exposure and a tool for soil biomonitoring $(10,20)$. The aim of our study was 1) to identify the sequence of P-gp/ $A B C B 1$ gene mRNA transcript in the earthworm and 2) to determine the modulation effects of MXR efflux activity in E. fetida by five different types of inhibitors. 


\section{MATERIALS AND METHODS}

\section{Chemicals}

Verapamil hydrochloride (CAS No. 152-11-14; VER), cyclosporine A (CAS No. 59865-13-3; CA), MK-571 sodium salt hydrate (CAS No. 115103-85-0; MK571), probenecid (CAS No. 57-66-9; PROB), sodium orthovanadate (CAS No. 13721-39-6; OV), rhodamine 123 (CAS No. 62669-70-9; R123), rhodamine B (CAS No. 81-88-9; RB), ampicillin (CAS No. 7177-48-2), isopropyl $\beta$-D-1thiogalactopyranoside (CAS No. 367-93-1; IPTG), and 5-bromo-4-chloro-3-indolyl $\beta$-D-galactoside (CAS No. 7240-90-6; X-Gal) were obtained from Sigma-Aldrich (St. Louis, MO, USA). Phosphate buffered saline (PBS: $\mathrm{NaCl} 0.138 \mathrm{~mol} \mathrm{~L}^{-1} ; \mathrm{KCl}$ $0.0027 \mathrm{~mol} \mathrm{~L}^{-1} ; \mathrm{pH}$ 7.4) and Luria Bertani medium (LB: $1.0 \%$ tryptone, $0.5 \%$ yeast extract, $1.0 \% \mathrm{NaCl}$; $\mathrm{pH}$ 7.0) were also prepared with chemicals obtained from Sigma-Aldrich.

\section{Test organism}

For each paper contact experiment we used 75-80 adult specimens of earthworm (Eisenia fetida Savigny, 1826) weighing 120-250 mg, raised on a culture and kept in the dark at $20 \pm 1^{\circ} \mathrm{C}$. Before each experiment, the earthworms were removed from the culture and placed on moist filter paper in Petri dishes for $24 \mathrm{~h}$ (still in the dark and at $20 \pm 1{ }^{\circ} \mathrm{C}$ ) to empty the gut content.

\section{Identification of P-gp/ABCB1-related mRNA transcript}

Primers P-gp-F and P-gp-R (F: 5'-GCGGCTGTGGGAAGAGCAC-3', R: 5'TGTTGTCTCCGTAGGCAATGTT-3') for the amplification of the $A B C B 1$ gene were designed based on the available, highly conserved mammalian, fish, and invertebrate $A B C B 1$ genes (Homo sapiens, Bos taurus, Tetraodon nigroviridis, Fundulus heteroclitus, Platichthys flesus, and Caenorhabditis elegans) and were obtained from Invitrogen (Carlsbad, CA, USA). The upstream primer matches the upstream part of the Walker A module to encompass the consensus nucleotide-binding domain (NBD) sequence GXXGXGKST. This motif embodies the glycine-rich phosphate-binding loop or P-loop in the NBDs.Total RNA samples were extracted using an EZ-10 Spin Column Total RNA Mini-preps Super Kit
(Bio Basic Inc., Ontario, Canada) (21). Approximately $100 \mathrm{mg}$ of earthworm tissue was homogenised in $450 \mu \mathrm{L}$ buffer RLT by sonication for $30 \mathrm{sec}$ (UltraTurrax T18 homogeniser, IKA, Germany). Other steps of RNA purification were performed according to manufacturer's instructions. Quality and quantity of each RNA sample was analysed with a BioSpec-nano apparatus (Shimatzu Biotech, Kyoto, Japan). Next, $1 \mu \mathrm{g}$ of total RNA was reversely transcribed with the PrimeScript First Strand cDNA Synthesis Kit (TaKaRa Bio Inc, Kyoto, Japan) (21) following the manufacturer's instructions and using OligodT primer and random hexamers. The obtained cDNA was then used as a template ( $2 \mu \mathrm{L}$ per reaction) for the $A B C B 1$ gene fragment amplification.

Polymerase chain reaction (PCR) was performed with the following mixture: $0.5 \mu \mathrm{mol} \mathrm{L}{ }^{-1} \mathrm{P}-g p-F$ and P-gp-R primers, $200 \mu \mathrm{mol} \mathrm{L}^{-1} \mathrm{dNTPs}$, 1x Q5 reaction buffer and $0.02 \mathrm{U}$ of Q5 High-Fidelity DNA Polymerase (EC 2.7.7.7) (New England BioLabs, Beverly, MA, USA) in the total volume of $50 \mu \mathrm{L}$. Cycling parameters were: one cycle of denaturation at $98^{\circ} \mathrm{C}$ for $30 \mathrm{~s}$ followed by 32 cycles of denaturation at $98^{\circ} \mathrm{C}$ for $10 \mathrm{~s}$, annealing at $58^{\circ} \mathrm{C}$ for $20 \mathrm{~s}$, extension at $72{ }^{\circ} \mathrm{C}$ for $30 \mathrm{~s}$, and final extension at $72{ }^{\circ} \mathrm{C}$ for $2 \mathrm{~min}$. This procedure yielded a DNA fragment of $\sim 200 \mathrm{bp}$, as confirmed by electrophoresis on $1 \%$ agarose gel. The amplimer was excised and purified using a QIAquick Gel Extraction Kit (Qiagen, Hilden, Germany) (22).

Before TA-cloning, $10 \mu \mathrm{L}$ of DNA fragment was A-tailed with $1 \mu \mathrm{L}$ of $2 \mathrm{mmol} \mathrm{L}^{-1} \mathrm{dATP}, 1 \mu \mathrm{L}$ of $10 \mathrm{x}$ buffer, and $1 \mu \mathrm{L}(5 \mathrm{U})$ of Ex-Taq polymerase (EC 2.7.7.7), totalling $10 \mu \mathrm{L}$, (TaKaRa Bio Inc, Kyoto, Japan) at $72{ }^{\circ} \mathrm{C}$ for $30 \mathrm{~min}$. The DNA fragment was then TA-cloned using the pGEM-T Vector System (Promega, Madison, WI, USA) (23) according to the manufacturer's instructions. Rubidium chloridetreated Escherichia coli competent cells were transformed using ligation mixture (21), plated onto LB/ampicillin/IPTG/X-Gal plates, and incubated at $37{ }^{\circ} \mathrm{C}$ overnight. Positive colonies (white) were selected and grown overnight at $37^{\circ} \mathrm{C}$ in $2 \mathrm{~mL}$ of the Luria-Bertani medium supplemented with ampicillin $\left(100 \mu \mathrm{g} \mathrm{mL}^{-1}\right)$. Plasmids were isolated using the QIAprep Miniprep kit (Qiagen) (21) and inserts were sequenced on an ABI PRISM ${ }^{\circledR}$ 3100-Avant Genetic Analyser (Applied Biosystem, Carlsbad, CA, USA) using the ABI PRISM BigDye Terminator v 3.1 Ready Reaction Cycle Sequencing Kit and pUC/M13 forward and reverse primers (Promega, Madison, WI, USA). 


\section{$\mathrm{ABCB} 1$ sequence analysis}

The obtained, partial P-gp/ABCB 1 cDNA sequence was further analysed using the National Center for Biotechnology Information (NCBI) basic alignment search tools tBlastx and Blastp. Multiple sequence alignments and determinations of identity rates between deduced amino acid sequences of $\mathrm{ABC}$ transporters from different species were performed using BioEdit software and Clustal X version 2.0 incorporated in the MEGA 5 software (24), both set at default parameters. We used the obtained alignment for phylogenetic reconstruction relying on NeighborJoining (NJ) and maximum likelihood (ML) analysis. For the construction of the NJ tree we used the MEGA 5 software. Reliabilities of phylogenetic relationships were evaluated using a non-parametric bootstrap analysis with 1,000 replicates (25). Bootstrap values exceeding 70 were considered well supported. Before the construction of the ML tree, we determined $\mathrm{LG}+\mathrm{G}$ (26) as the optimal model of protein evolution using the PROTTEST 2.4 server (27). The tree was constructed using PhyML 3.0 (28) and was improved with five random starting trees using both subtree pruning and regrafting and nearest neighbour interchange (29). Branches were tested with the approximate likelihood-ratio test (30).

\section{Exposure of earthworms to model MXR inhibitors}

To determine MXR activity in adult E. fetida we used the filter paper contact test method (5). The principle of this in vivo assay is to measure bioaccumulation of a model fluorescent substrate in the whole body of the earthworm. Exposure is done in the absence (control group) or presence of a model MXR inhibitor. We used two fluorescent model MXR substrates - rhodamine B (RB) and rhodamine 123 (R123) - and five MXR inhibitors - verapamil (VER), cyclosporine A (CA), MK571, probenecid (PROB), and sodium orthovanadate (OV). The following procedure was used: earthworms were placed into 90-mm Petri dishes with filter paper at the bottom, damped with $1.7 \mathrm{~mL}$ of tested chemicals. Five earthworms were placed in each Petri dish for each treatment group $(\mathrm{n}=5)$ and the measurement was done in triplicate. The final concentrations of MXR inhibitors and fluorescent substrates were as follows: VER - $10 \mu \mathrm{mol} \mathrm{L}{ }^{-1}$, CA - $10 \mu \mathrm{mol} \mathrm{L} \mathrm{L}^{-1}$, MK571 $50 \mu \mathrm{mol} \mathrm{L}{ }^{-1}$, OV - $100 \mu \mathrm{mol} \mathrm{L}^{-1}$, PROB - $500 \mu \mathrm{mol} \mathrm{L}^{-1}$, and RB and R123 - $10 \mu \mathrm{mol} \mathrm{L}^{-1}$. Earthworms were first exposed to the inhibitor for $24 \mathrm{~h}$ (pre-treatment) and then transferred to a mixture of the inhibitor and fluorescent substrate for additional $24 \mathrm{~h}$ or $48 \mathrm{~h}$. All Petri dishes were kept in the dark at $20 \pm 1{ }^{\circ} \mathrm{C}$.

\section{Measurement of rhodamine fluorescence}

The amount of accumulated RB or R123 was measured 24 and $48 \mathrm{~h}$ after exposure. For sample preparation, whole earthworms were weighed and then homogenised with the Ultra-Turrax T18 homogeniser (IKA, Königswinter, Germany) in $2 \mathrm{~mL}$ of cold PBS and centrifuged at $9000 \mathrm{~g}$ for $10 \mathrm{~min}$. Supernatant was transferred to black 96-well microplates (Nunc, Thermo Fisher Scientific, Hvidovre, Denmark). The amount of fluorescent dye in the supernatant was determined in triplicate using FLUOstar OPTIMA plate reader (BMG Labtech Ltd., Aylesbury, UK) with excitation at $544 \mathrm{~nm}$ and emission at $590 \mathrm{~nm}$ for RB and excitation at $490 \mathrm{~nm}$ and emission at $544 \mathrm{~nm}$ for R123.

\section{Statistical analysis}

Before the statistical analysis of accumulated florescence in treated tissues, each sample was normalised relative to non-treated controls (i.e. background fluorescence was subtracted from each reading). Background fluorescence in tissues with no RB did not differ from that of the phosphate buffer extraction medium $(p<0.05)$. All experiments were performed at least three times and mean values and standard deviations (SD) determined. The results for rhodamine dye accumulation were expressed as fluorescent units per $\mathrm{mg}$ of earthworm tissue $\left(\mathrm{FU} \mathrm{mg}^{-1}\right)$ and then plotted as percent of control values for final comparison. Significant differences were determined using the unpaired Student's $t$-test. Data are presented as mean $\pm \mathrm{SD}$ using Daniel's XL Toolbox open-source add-in for the Microsoft ${ }^{\circledR}$ Excel $^{\circledR}$ spreadsheets.

\section{RESULTS}

\section{Identification of P-gp/ABCB1-related sequence in E. fetida}

Specific pairs of primers (P-gp-F and P-gp-R) generated a fragment which after cloning and sequencing resulted in the following $154 \mathrm{bp}$ partial ABCB 1 sequence: 5'-AATTGTCCAGCTA CTGGAGAGATTCTACGATATTCCTGAGG GA C A A G T GAT GG T G GAT G G T C GC G 
ATGTGAAGTCATTGAACGTCGCTTGGTTG AGAGCTCAGCTGGGCATTGTCTCCCAGGAAC CGACTCTCTTTGACTGTAGCATTCGAGAA-3'. The amplified fragment corresponds to the Walker A module and the translated 51 amino acids were: I V Q L L E R F Y D I P E G Q V M V D G R DVKSLNVAWLRAQLGIVSQEPTLFDCSIRE. This partial PCR product showed a high degree of identity with P-gp from various other organisms (Figure 1), and this homology was confirmed with NCBI Blast2 Protein Database Query (data not shown). Multiple alignment of P-gp sequences is shown in Figure 2(b).

\section{Phylogenetic analysis}

We used phylogenetic analysis to establish the relationship between the identified P-gp/ABCB1 transport protein sequence and other available $\mathrm{ABC}$ transporters. The identified sequence grouped well within the $\mathrm{ABCB}$ subfamily. The $\mathrm{NJ}$ tree is presented in Figure 2(a). ML analysis confirmed the position of the identified $E$. fetida sequence in ABCB subfamily (data not shown).

\section{Accumulation of rhodamine substrates in the presence of MXR inhibitors}

The filter paper contact test showed significant accumulation of both R123 and RB in whole earthworm tissue (Figure 3). Control values of R123 accumulation were 1.5 and 2.5 times higher than for $\mathrm{RB}$, after 24 and $48 \mathrm{~h}$, respectively (data not shown). Twenty-four-hour exposure significantly increased overall accumulation of R123 when MK571 and OV were used (48\% and $95 \%$ increase, respectively; $p<0.05)$. After $48 \mathrm{~h}$, significant increase was observed with MK571, VER, and OV (42\%, $34 \%$, and $88 \%$, respectively, Figure 3a). When RB was used in the same set of experiments, significant increase in dye

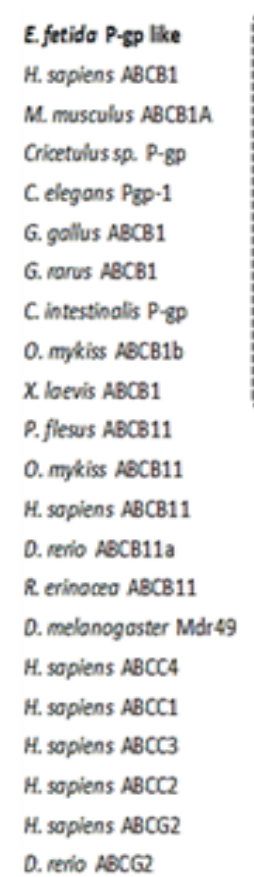

Figure 1 Percentage of identity between E. fetida P-gp like fragment protein sequence and other ABC transporters (based on ClustalW alignment, BioEdit) 


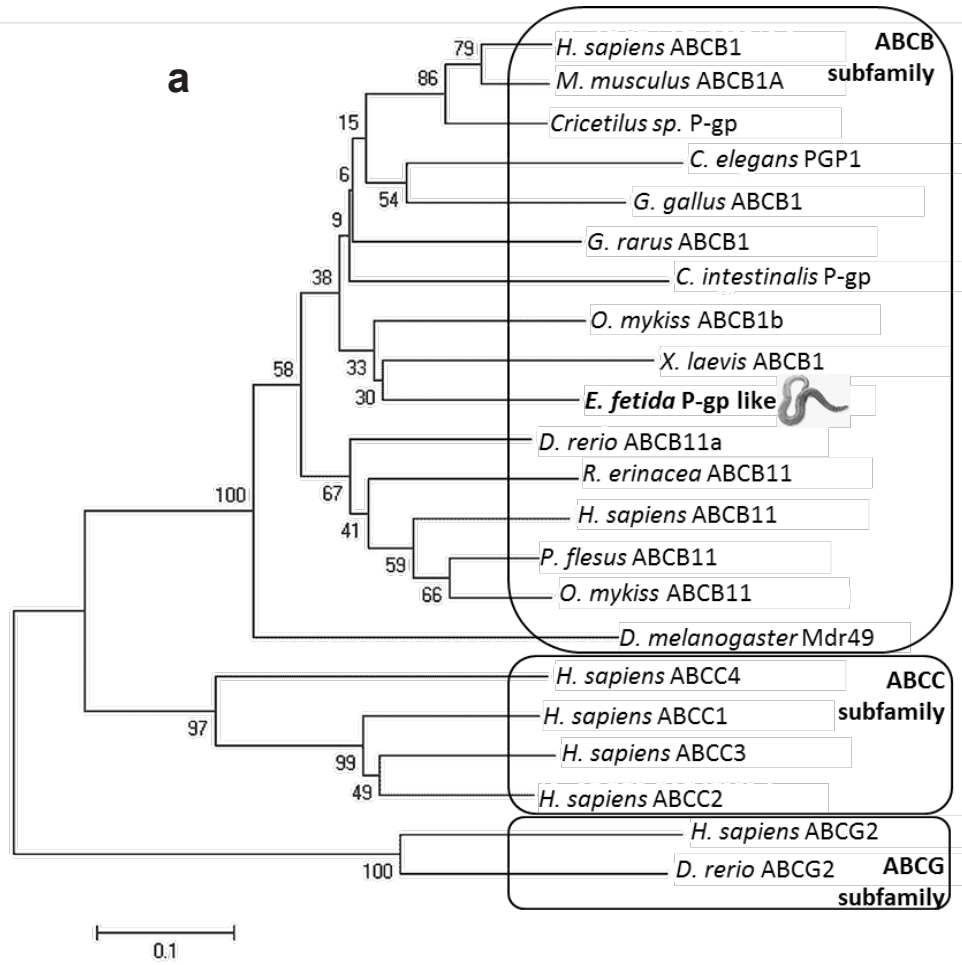

b $\begin{array}{llll}10 & 20 & 30 & 40\end{array}$

H. sapiens VVLLLRPYDPLAGKVLLDGKBIRRLNVCWLFABLGIVSQBPILPDCSIAB

M. musculus VVQLLRRPYDPNAGSVPLDGKBIRQLNVCWLFAQLGIVSQBPILPDCSIAB

Cricetilus sp. VVQLLRRPYDPNAGTVLLDGQEARRLNICWLFAQLGIVSQBPVLPDCSIAB

C. elegans WALLRRPYDTLGGEIPIDGSBIRTLNPBBTRSQIAIVSQBPTLPDCSIAB

G. gallus WQLLRRPYDPLSGBIVPDDICARTLNIC्रWLRSHIGIVSQBPILPDPTIAB

G. rarus TIQLLRRPYDFQQGKWLDENCARQLNIEWLRSQIGIVSQBPVLPDCSLAB

c. intestinalis VIQLIRRPYCVAGGVVLLDCVDIRLLNVEWLRGQIGLVSQBPSLPNQNIRB

0. mYkiss SIQLLRRPYSEAEGCVLVDGLDTRTLNLSWLRSQLGLVSQRPILPDCSISB

X. laevis TVSLLRRPYDPRBGEVLVDGLSVRNLNIC WVAQVYGIVSQBPILPDCSIGD

E. fetida IVQLLRRPYDIPEGCWNDGRDVRSLNVAWLFALLGIVSQBPTLPDCSIRB

Figure 2 (a) Neighbor-Joining tree showing the relation between E. fetida $P$-gp like protein and different ABC transporter subtype sequences from various vertebrates and invertebrates. Bootstrap support values are shown at the nodes (1000 replicates). The accession numbers of ABCB transporters are: NP 502413.1, XP 002122143.1, AAA53440.1, XP_001337724.3, NP_523724.2,NP 990225.1,AFK33289.1, NP_000918̄.2, NP_003733.2. NP_035206.2, ADO95108.1,

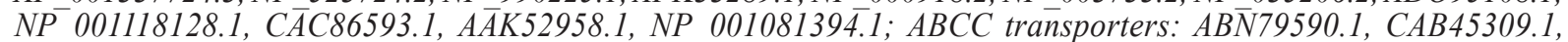
O15438.3, NP_005836.1; ABCG transporters: NP_01036240.1, NP_005836.1. (b) Multiple sequence alignment of E. fetida $P$-gp/ABCB1 and other P-gp/ABCB1-transporter sequences

accumulation was observed with MK571 and OV after $24 \mathrm{~h}(81 \%$ and $78 \%$, respectively), and only with MK571 after 48 h (88\%, Figure 3b).

\section{DISCUSSION}

This study is the first to have identified ABC efflux transporters in E. fetida and has shown that MXR efflux protein activity can be modulated by competitive and non-competitive inhibitors.

We obtained somewhat lower bootstrap support within the ABCB1 (P-gp) clade, presumably because we used a short sequence for alignment (51 amino acids). Therefore, for detailed determination of the phylogenetic position of E. fetida P-gp it will be necessary to obtain a longer sequence. However, this is the first $\mathrm{ABCB}$ sequence for the clade Annelida and 
it is long enough for future expression studies of the $A B C B 1$ gene using long-term exposure filter paper contact tests.

We optimised the test for $E$. fetida by modifying the procedure for $E$. andrei (10). Like Hackenberger et al. (10), we have established that it is important to pre-treat earthworms with inhibitors for at least $24 \mathrm{~h}$ before adding substrate to the filter paper, as it turns out that pre-treatment helps inhibitors to enter earthworm tissue.

However, we obtained different fluorescence accumulation for RB and R123. R123 showed significant MXR inhibition with MK571, VER, and $\mathrm{OV}$, and RB with to MK571 and OV. In addition, RB accumulation was 1.5 times $(24 \mathrm{~h})$ and 2.5 times $(48 \mathrm{~h})$ lower than that of R123 in controls (data not shown). This suggests that R123 is the dye of choice for research with earthworms as model organisms. In our earlier study on several marine and freshwater invertebrates (16), the accumulation of these two substrates also differed, but that time in favour of RB.

Using different types of MXR inhibitors we were able to determine the dominant type of $\mathrm{ABC}$ transporter in E. fetida. OV inhibits a number of ATPases. VER and CA are known to inhibit P-gp/ ABCB1 efflux pump, whereas MK571 and PROB inhibit MRP/ABCC-like activity (32-33). E. fetida seems to combine P-gp/ABCB1 and MRP/ABCC-like

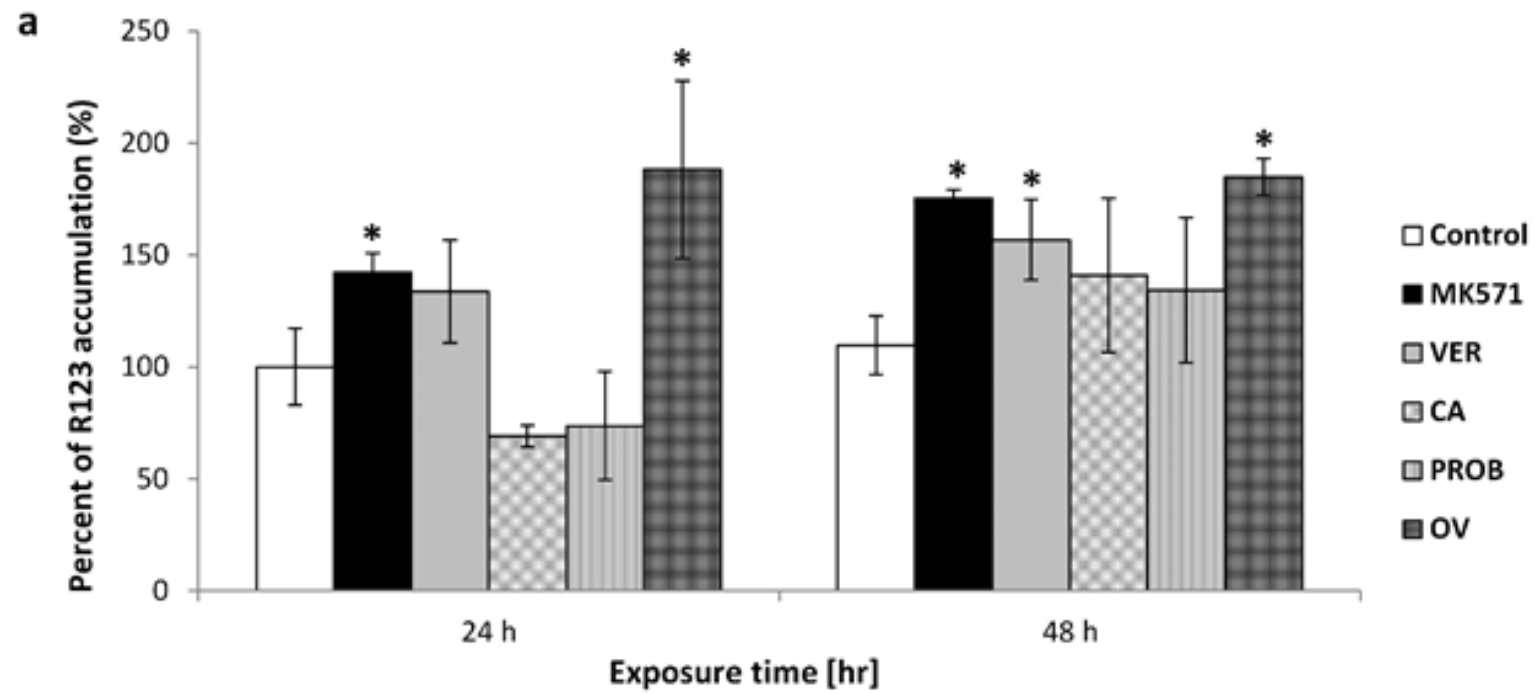

b

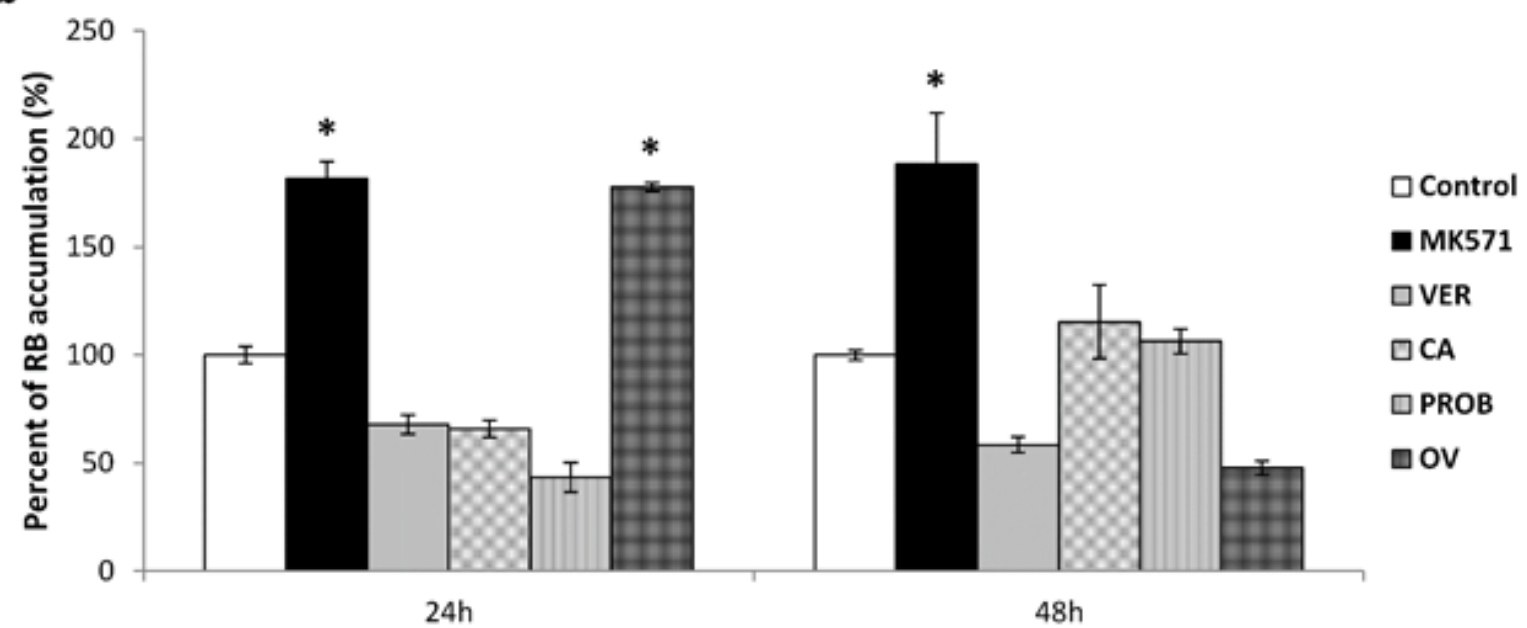

Figure 3 Accumulation of rhodamine dye in earthworm E. fetida after pre-treatment with different MXR inhibitors (50 $\left.\mu \mathrm{mol} \mathrm{L} \mathrm{L}^{-1} \mathrm{MK571}, 10 \mu \mathrm{mol} \mathrm{L} \mathrm{L}^{-1} \mathrm{VER}, 10 \mu \mathrm{mol} \mathrm{L} \mathrm{L}^{-1} \mathrm{CA}, 500 \mu \mathrm{mol} \mathrm{L} \mathrm{L}^{-1} \mathrm{PROB}, 100 \mu \mathrm{mol} \mathrm{L} \mathrm{L}^{-1} \mathrm{OV}\right)$ followed by exposure to rhodamine 123 (R123) (a) or rhodamine $B(R B)$ (b) for 24 or 48 h. Data are expressed as the mean of triplicate $\pm S D$. ${ }^{*} \mathrm{p}<0.05, t$-test, $n=5$ 
activity. Although we detected a P-gp sequence, MK571 showed higher inhibition than VER and CA, which suggests that MRP proteins dominate over P-gp. Unfortunately, we could not identify any MRP-related genes.

One of the interesting findings was lower fluorescence in earthworms exposed to CA and PROB than in control, regardless of the dye. Lower fluorescence was more pronounced with RB than with R123 and could be explained by varying expression of MXR efflux pumps. Additional experiments are needed for a more definitive conclusion.

Chemicals that are capable of inhibiting the MXR mechanism should rank high among environmentally hazardous chemicals because they threaten the basic biological defence and can revert natural resistance to disease $(7,9,12,16,17)$. In addition, environmental samples expressing reverse MXR potential should be monitored and controlled. Our results show that $E$. fetida can serve well as a test organism for environmental pollutants with the potential to inhibit MXR activity.

\section{CONCLUSION}

This study has demonstrated that: a) the MXR defence system in earthworm E. fetida is at least partly mediated by the P-gp efflux transporter; b) the identified sequence is closest to the ABCB subfamily; c) MXR activity can be decreased by specific inhibitors (VER, MK571, OV), resulting in significant R123/RB accumulation in earthworm tissue; and d) R123 is the substrate of choice in E. fetida as model organism. These new findings should help to better characterise and identify all $\mathrm{ABC}$ proteins that may be involved in MXR in E. fetida.

In addition, optimised filter paper contact test could be a valuable tool for the toxicological assessment of polluted soil samples that contain MXR inhibitors, while the expression of the P-gp gene (up or down regulation) has a great potential to become a biomarker of pollution response.

\section{Acknowledgements}

This work was supported by the Ministry of Science, Education and Sports of the Republic of Croatia, Project No 058-0582261-2246 and 0981782739-2749. We thank Dr Saša Likić (Faculty of
Science, Zagreb, Croatia) for technical help with the FLUOstar OPTIMA plate reader.

\section{REFERENCES}

1. Luo Y, Zang Y, Zhong Y, Kong Z. Toxicological study of two novel pesticides on earthworm Eisenia foetida. Chemosphere 1999;39:2347-56. doi: 10.1016/S0045-6535(99)00142-3

2. Markman S, Guschina IA, Barnsley S, Buchanan KL, Pascoe D, Müller CT. Endocrine disrupting chemicals accumulate in earthworms exposed to sewage effluent. Chemosphere 2007;70:119-25. doi: 10.1016/j.chemosphere.2007.06.045

3. Garcia M. Römbke J, de Brito MT, Scheffczyk A. Effects of three pesticides on the avoidance behavior of earthworms in laboratory tests performed under temperate and tropical conditions. Environ Pollut 2008;153:450-6. doi:10.1016/j. envpol.2007.08.007

4. Sinha R. Earthworms: the miracle of nature (Charles Darwin's 'unheralded soldiers of mankind \& farmer's friends'). The Environmentalist 2009;29:339-40. doi: 10.1007/s10669-009-9242-4

5. Organisation for Economic Cooperation and Development (OECD). OECD Guidelines for Testing of Chemicals. Section 2. Effects on Biotic Systems. Test No. 207: Earthworm, Acute Toxicity Tests (Filter Paper Test and Artificial Soil Test). Paris: OECD; 1984.

6. Goldstone JV, Hamdoun A, Cole BJ, Howard-Ashby M, Nebert DW, Scally M, Dean M, Epel D, Hahn ME, Stegeman JJ. The chemical defensome: environmental sensing and response genes in the Strongylocentrotus purpuratus genome. Dev Biol 2006;300:366-84. doi: 1016/j.ydbio.2006.08.066

7. Epel D, Luckenbach T, Stevenson CN, MacManus-Spencer LA, Hamdoun A, Smital T. Efflux transporters: newly appreciated roles in protection against pollutants. Environ Sci Technol 2008;42:3914-20. PMID: 18589945

8. Sauerborn Klobučar R, Žaja R, Franjević D, Brozović A, Smital T. Presence of ecotoxicologically relevant P-gp and MRP transcripts and proteins in cyprinid fish. Arh Hig Rada Toksikol 2010;61:175-82. doi: 10.2478/10004-1254-612010-2008

9. Bošnjak I, Uhlinger KR, Heim W, Smital T, Franekić Čolić J, Coale K, Epel D, Hamdoun A. Multidrug efflux transporters limit accumulation of inorganic, but not organic, mercury in sea urchin embryos. Environ Sci Technol 2009:43:8374-80. doi: 10.1021/es901677r

10. Hackenberger BK, Velki M, Stepic S, Hackenberger DK. First evidence for the presence of efflux pump in the earthworm Eisenia andrei. Ecotoxicol Environ Saf 2012;75:40-5. doi: 10.1016/j.ecoenv.2011.06.024

11. Leslie EM, Deeley RG, Cole SPC. Multidrug resistance proteins: role of P-glycoprotein, MRP1, MRP2, and BCRP (ABCG2) in tissue defense. Toxicol Appl Pharmacol 2005;204:216-37. PMID: 15845415

12. Szakács G, Váradi A, Özvegy-Laczka C, Sarkadi B. The role of $\mathrm{ABC}$ transporters in drug absorption, distribution, metabolism, excretion and toxicity (ADME-Tox). Drug Discov Today 2008;13:379-93. doi: 10.1016/j. drudis.2007.12.010

13. Lespine A, Ménez C, Bourguinat C, Prichard RK. P-glycoproteins and other multidrug resistance transporters 
in the pharmacology of anthelmintics: Prospects for reversing transport-dependent anthelmintic resistance. Int J Parasitol Drugs Drug Resist 2012;2:58-75. doi: 10.1016/j. ijpddr.2011.10.001

14. Kurelec B, Krča S, Pivčević B, Ugarković D, Bachmann M, Imsiecke G, Müller WEG. Expression of P-glycoprotein gene in marine sponges. Identification and characterization of the $125 \mathrm{kDa}$ drug-binding glycoprotein. Carcinogenesis 1992;13:69-76. doi: 10.1093/carcin/13.1.69

15. Minier C, Akcha F, Galgani F. P-glycoprotein expression in Crassostrea gigas and Mytilus edulis in polluted seawater. Comp Biochem Physiol B Biochem Mol Biol 1993;106:102936. PMID: 7905372

16. Smital T, Sauerborn R, Pivčević B, Krča S, Kurelec B Interspecies differences in P-glycoprotein mediated activity of multixenobiotic resistance mechanism in several marine and freshwater invertebrates. Comp Biochem Physiol C Pharmacol Toxicol Endocrinol 2000;126:175-86. PMID 11050689

17. Bard SM, Woodin BR, Stegeman JJ. Expression of P-glycoprotein and cytochrome p450 1A in intertidal fish (Anoplarchus purpurescens) exposed to environmental contaminants. Aquat Toxicol 2002;60:17-32. doi: 10.1016/ S0166-445X(01)00272-7

18. Smital T, Sauerborn R, Hackenberger BK. Inducibility of the P-glycoprotein transport activity in the marine mussel Mytilus galloprovincialis and the freshwater mussel Dreissena polymorpha. Aquat Toxicol 2003;65:443-65. doi: 10.1016/S0166-445X(03)00175-9

19. Hamdoun AM, Cherr GN, Roepke TA, Epel D. Activation of multidrug efflux transporter activity at fertilization in sea urchin embryos (Strongylocentrotus purpuratus). Dev Biol 2004;276:452-62. doi: 10.1016/j.ydbio.2004.09.013

20. Sinha RK, Chauhan K, Valani D, Chandran V, Soni BK, Patel V. Earthworms: Charles Darwin's "unheralded soldiers of mankind": Protective \& productive for man \& environment. J Environ Prot 2010;1:251-60. doi: 10.4236/jep.2010.13030

21. Sambrook J, Fritsch EF, Maniatis T. Molecular Cloning: a Laboratory Manual. Cold Spring Harbor (NY): Cold Spring Harbor Laboratory; 1989.

22. Vogelstein B, Gillespie D. Preparative and analytical purification of DNA from agarose. Proc Natl Acad Sci USA 1979;76:615-9. PMCID: PMC382999
23. Knoche K, Kephart D. Cloning blunt-end Pfu DNA Polymerase-generated PCR fragments into $\mathrm{PGEM} \AA-T$ Vector Systems. Promega Notes 1999;71:10-3.

24. Tamura K, Peterson D, Peterson N, Stecher G, Nei M, Kumar S. MEGA5: molecular evolutionary genetics analysis using maximum likelihood, evolutionary distance, and maximum parsimony methods. Mol Biol Evol 2011;28:2731-9. doi: 10.1093/molbev/msr121

25. Hillis DM, Bull JJ. An empirical test of bootstrapping as a method for assessing confidence in phylogenetic analysis. Syst Biol 1993;42:182-92. doi: 10.1093/sysbio/42.2.182

26. Le SQ, Gascuel O. An improved general amino-acid replacement matrix. Mol Biol Evol 2008;25:1307-20. doi: 10.1093/molbev/msn067

27. Abascal F, Zardoya R, Posada D. ProtTest: Selection of bestfit models of protein evolution. Bioinformatics 2005;21:21045. doi: 10.1093/bioinformatics/bti263

28. Guindon S, Dufayard JF, Lefort V, Anisimova M, Hordijk $\mathrm{W}$, Gascuel $\mathrm{O}$. New algorithms and methods to estimate maximum-likelihood phylogenies: assessing the performance of PhyML 3.0. Syst Biol 2010;59:307-21. doi: 10.1093/ sysbio/syq010

29. Hordijk W, Gascuel O. Improving the efficiency of SPR moves in phylogenetic tree search methods based on maximum likelihood. Bioinformatics 2005;21:4338-47. doi: 10.1093/bioinformatics/bti713

30. Anisimova M, Gascuel O. Approximate likelihood-ratio test for branches: a fast, accurate, and powerful alternative. Syst Biol 2006;55:539-52. doi: 10.1080/10635150600755453

31. Dean M, Rzhetsky A, Allikmets R. The human ATP-binding cassette $(\mathrm{ABC})$ transporter superfamily. Genome Res 2001;11:1156-66. doi: 10.1101/gr.184901

32. Fischer E, Beuschlein F, Bidlingmaier M, Reincke M. Commentary on the endocrine society practice guidelines: Consequences of adjustment of antihypertensive medication in screening of primary aldosteronism. Rev Endocr Metab Disord 2011;12:43-8. doi: 10.1007/s11154-011-9163-7

33. Gekeler V, Ise W, Sanders KH, Ulrich WR, Beck J. The leukotriene LTD4 receptor antagonist Mk571 specifically modulates MRP associated multidrug resistance. Biochem Biophys Res Commun 1995;208:345-52. PMID: 7887949 


\section{Sažetak}

Prvi dokaz ekspresije gena za P-glikoprotein (P-gp/ABCB1) i djelovanja inhibitora na multiksenobiotičku otpornost u gujavice

Mehanizam multiksenobiotičke otpornosti (MXR) prisutan je u mnogim organizmima kao važan stanični detoksikacijski mehanizam. Posredovan je aktivnošću ABC prijenosnika koji vežu i aktivno izbacuju različite toksične tvari iz stanice. U ovom radu dani su podaci o molekularnoj identifikaciji ABC prijenosnika (eksportera) - P-glikoproteina (P-gp/Abcb1), kao jednog od predstavnika MXR fenotipa, u gujavici Eisenia fetida. Određen je djelomični slijed identificiranoga gena $A b c b 1$, njegov predviđeni aminokiselinski slijed uspoređen je s ABCB1 homolozima iz drugih organizama i utvrđena je identičnost od 58,5 do72,5 \%. Uz to, istraživali smo učinak pet modulatora (verapamil, ciklosporin, MK571, probenecid, ortovanadat) na aktivnost MXR mehanizma tih gujavica. Kako bismo potvrdili modulirajuće djelovanje istraživanih modelnih inhibitora na MXR mehanizam u E. fetida, mjerili smo akumulaciju modelnih supstrata rodamina B (RB) i rodamina 123 (R123) u tijelu spolno zrelih jedinki gujavica testom izlaganja na filtar papiru. Rezultati su pokazali da svi istraživani modulatori značajno inhibiraju MXR transportnu aktivnost. Naši podaci prvi upućuju na prisutnost P-gp/Abcbl srodnih gena u gujavici E. fetida. Osim toga, ukazali smo na veliku važnost MXR-a kao specifičnog detoksikacijskog mehanizma koji omogućuje preživljavanje gujavica u onečišćenom okolišu.

KLJUČNE RIJEČI: ABC prijenosni proteini; ciklosporin A; Eisenia fetida; MK571; organizam iz tla; ortovanadat; probenecid; stanični mehanizam detoksikacije; verapamil

\section{CORRESPONDING AUTHOR:}

Roberta Sauerborn Klobučar

Ruđer Bošković Institute

Division of Materials Chemistry

Bijenička cesta 54, 10000 Zagreb, Croatia

E-mail: rsauer@irb.hr 